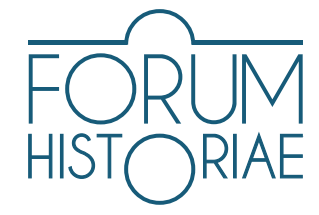

\title{
Yugoslav Ruling Of Rijeka (Fiume) in 1918, Seen by Stanislaw Krakow
}

\author{
Biljana Stojić
}

\begin{abstract}
STOJIĆ, Biljana. Yugoslav Ruling Of Rijeka (Fiume) in 1918, Seen by Stanislaw Krakow.

This paper discusses a short but very important episode of First World War history concerning the Yugoslav ruling over Rijeka (Fiume) in 1918 as seen through the war experience and writings of Stanislaw Krakow. In the interwar period, Krakow became one of the most known representatives of Expressionism while at the same time a prominent journalist, philatelist, numismatist, art collector, movie director, etc. As a writer, he dedicated a few works to the Rijeka events where he participated as an officer in the Serbian battalion sent from the Thessaloniki front to "cross over every Yugoslav province in order to bring them freedom and to announce unification of Southern Slavs." Krakow spent one month in Rijeka, arriving on 15 November, but when the Serbian army withdrew two days later he stayed as a Serbian representative within the international mission of French General Andre Tranié. During the month spent in Rijeka, Krakow was witness to many conflicts among pro-Italians and pro-Yugoslavs amid a tense atmosphere with diplomatic clashes between great powers. Describing the early phase of Rijeka's crisis, Krakow added his own unique angle to the events and we believe that perspective and his extraordinary life story are worthy of presentation to the public appreciation. For the purpose of this paper we rely on his writings as a base for our research, accompanied by documents stored in the Archive of Yugoslavia, the National Library of Serbia, relevant historiography works and newspapers.
\end{abstract}

Keywords: Stanislaw Krakow, Franchet d'Espèrey, First World War, Rijeka (Fiume), Serbia, Italy, Yugo Slavism, 1918 DOI: https://doi.org/10.31577/forhist.2021.15.1.5

G eneral Franchet d'Espèrey, the third and last commander of L'Armée d'Orient, came to Thessaloniki in June 1918. Unlike his predecessors, Generals Maurice Sarrail and Adolphe Guillaumat, d'Espèrey immediately decided to change the existing war strategy. Instead of sending armies into smaller attacks, he pooled his resources into one large strike targeting a penetration of the frontline. Along with other allied commanders, he assessed that continuing the previous tactic of local attacks was and will be counterproductive because "causes for the bravest getting killed and a huge amount of ammunition is going to waste". ${ }^{1}$ The other characteristic that distinguished d'Espèrey from Sarrail and Guillaumat was his trust in the Serbian army. From first sight he recognized that Serbs have the most motivation in the ongoing war since only victory will bring them back to their homeland. After noting this, d'Espèrey trusted them to lead the entire Allied army into a final breakthrough. He needed only a few meetings with Serbian Regent Alexandre Karadjordjević and Chief of General Staff Živojin Mišić to reach an agreement and all three together drafted the final strategy. ${ }^{2}$ From the military point of view, the plan was ready at the beginning of July but from the point

1 D’EPERE, Luj Franše. Memoari. Solunski front, Srbija, Balkan, Centralna Evropa 1918-1919. Edited by Vojislav Pavlović. Novi Sad : Prometej, 2018, p. 62.

2 Veliki rat Srbije za oslobođenje i ujedinjenje Srba, Hrvata i Slovenaca 1914-1918. g., 1918. godina, III period rovovske vojne. Pripreme za ofanzivu, XXVI. Glavni Đeneralštab : Beograd, 1935, pp. 96-97; D’EPERE 2018, p. 59; KRAKOV, Stanislav. Naše poslednje pobede. Beograd : Vreme, 1928, p. 7. 
of view of politics the entire operation was far from completion. D'Espèrey's emissaries spent one month getting diplomatic approval from Paris, London and Rome. The most hesitant towards the Thessaloniki front and the planned operation was French President of the Government and Minister of War Georges Clemenceau, who gave his consent on 10 September, just five days prior to the scheduled attack. Even after authorization was given, Clemenceau remained suspicious and clearly stated his concerns to d'Espèrey, underlining that the operation will be conducted entirely under his responsibility. ${ }^{3}$ Regardless of such distrust, General d'Espèrey scheduled artillery preparation for 14 September, following with an infantry attack the next day. Three Serbian armies supported with two French divisions and French artillery started breaching the frontline on 15 September at 5:30 am. ${ }^{4}$ The front was penetrated the same day with Allied armies advancing ferociously without rest. The Serbian army liberated the entire country in just 45 days. The initial phase of the operation ended when the first Serbian army entered the capital, Belgrade, on 1 November.

\section{Life Road of Stanislaw Krakow and his Place in the Serbian Army}

At the beginning of the final operation, Sub-lieutenant Stanislaw Krakow was an adjutant in the $2^{\text {nd }}$ battalion, $5^{\text {th }}$ infantry regiment within the Second Serbian Army under the command of General Stepa Stepanović. ${ }^{5}$ Like all Serbian soldiers, Krakow cheerfully welcomed the announcement of the offensive, describing the moment as "accomplishment of all our long-lasting hopes. For other armies' operation in September 1918 will be just one of many while for the Serbian army it will be a 'to be or not be moment' which the outcome will either bring us back home or turn into defeat until last living soldier". ${ }^{6}$

He was only 22 in 1918, but behind him was already seven long years of warfare. He signed up to the army as a volunteer in the Balkan Wars, (October 1912 - August 1913) at $17 .^{7}$ From those wars he emerged as a famous child-soldier. The magazine from Novi Sad, Illustrated War Chronicles, dedicated a long article to Krakow which described that he returned from the First Balkan War with Zeki-Pasha's coat and rifle, (commander of Turkish army in Kumanovo battle), while in the Second he got his first war wound. ${ }^{8}$ Until the end of the Great War, he was wounded 14 times in total, along with suffering from mumps (1913), cholera (1915), malaria (1916) and Spanish flu (1918). ${ }^{9}$ For his

3 STOJIĆ, Biljana. Georges Clemenceau and creation of Yugoslavia. In RASTOVIĆ, Aleksandar - MILKIĆ, Miljan (eds.) End of the Great War - The Road to New Europe. Belgrade : Institute of History; Strategic Reaserch Institute, 2020, pp. 235-256.

4 Veliki rat Srbije za oslobodenje i ujedinjenje Srba, Hrvata i Slovenaca 1914-1918. g., 1918. godina, knj. 26, III period rovovske vojne. Pripreme za ofanzivu, Naređenja (izveštaji) Vrhovne komande Aktom Str. Pov. OBr. 26543 od 8. jula 1918 god - Komandantu II armije, p. 112.

5 General Stepa Stepanović was originally the creator of the operation plan which he presented to d'Espèrey in June 1918. D'Esperèy approved the plan, but made some minor changes on 24 August in order to simplify it and make it more effective. Originally General Stepanović predicted that armies from the second line would start marching only after the frontline was already breached. D'Esperèy noticed that the distance between the first and second line was 12 thousand - 13 thousand meters, which meant four to five hours of marching and that the enemy could use that time to recover and regain lost positions. This was the same mistake that France made in the Marna battle. To avoid that scenario, D’Espèrey planned for troop commanders from the first and second lines to share the same headquarters and that the second line follows the first without additional orders. This small change allowed the Yugoslav division at the head of the Serbian army to quickly seize the peak of the mountain Kozjak and with that enabled Germans and Bulgarians to react and send help. D'EPERE 2018, p. 81.

6 KRAKOV, Stanislav. Život čoveka na Balkanu. Beograd; Lausanne; Zemun : Naš dom; L’Age d'Homme; Fleš, 2009, p. 224.

7 STOJIĆ, Biljana. Francuska i balkanski ratovi (1912-1913). Beograd : Istorijski institut, 2017.

8 Narodna biblioteka Srbije (NBS, National library of Serbia), Rukopisno odeljenje (RO), Arhiva Stanislava Krakova (ASK), Ratni dnevnik 1912-1913, R 707/I/16-1; R 707/I/1b-11; KRAKOV 2009, pp. 32-33, 35, 38.

9 KRAKOV 2009, pp. 11-12. 
contributions, he was awarded 18 medals, three of which were foreign: L'Officier de l'ordre de la Couronne le Roumanie (1922); Palme d'Officier de l'Instruction Publique (1930) and Ordre du Phénix de la Grèce (1935). ${ }^{10}$

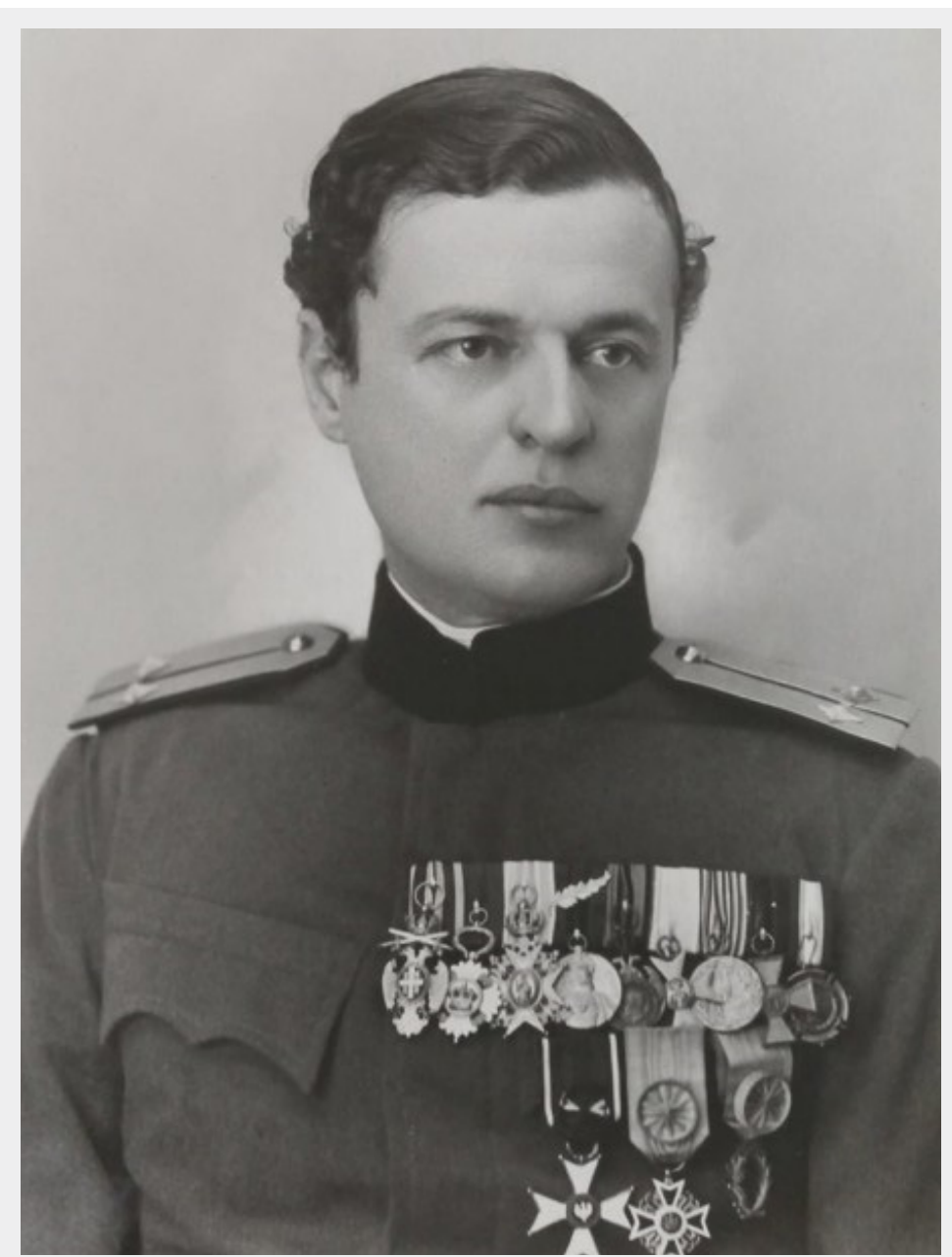

Figure 1. Stanislaw Krakow
The volunteer experience from the Balkan Wars, and even more his family background, predestined young Stanislaw Krakow for a military career. His father Sigismund (Zigmund) Krakow was a military doctor. He was born and raised in Poland, but after one of many unsuccessful rebellions against Russian supremacy he escaped to France. At the beginning of the war against Bulgaria in 1885, Serbia extended a call for foreign military medics and Sigismund applied for the position. When the war ended in 1886 , Sigismund decided to stay in Serbia and start a family with Persida Nedić and Stanislaw was born in Kragujevac on 29 March 1895. ${ }^{11}$

His mother was also from a military family. All three of Persida's brothers, Milan, Milutin and Božidar, were highly ranked offi-

cers in the Serbian, and later Yugoslav army. ${ }^{12}$ The oldest of the trio, Milan, was a general and governor in occupied Serbia under the Nazi regime 1941-1944. He had the biggest influence on his nephew since Stanislaw lost his father at young age, (1910), and his uncle(s) became the father figure in his life. ${ }^{13}$ Krakow began to study at the Military Academy in September 1913, as a second ranked cadet. Unfortunately, due to the outbreak of the First World War (WWI), he spent only half a year at the Academy. Serbia was desperately lacking soldiers so even with only a few months of study, Krakow was considered a professional soldier and as such was sent into the trenches. In autumn 1915, he was positioned on the South-East border with Bulgaria when his battalion was attacked by the Bulgarian army. During the fighting he was severely injured but managed to recover before the withdrawal of the army in November-December 1915. After reorganization and transfer of the army from Corfu to Thessaloniki in April-May 1916, Krakow was immediately assigned

10 NBS, RO, ASK, R 707/III/14, No. 990, Ministerul Afacerilor Sträine - Cancelaria ordinelor, Accusé de Réception, Belgrade, le 25 mars 1922; NBS, RO, ASK, R 707/III/13, Légation de France Belgrade, le 12 septembre 1930.

11 Arhiv Jugoslavije (AJ, Archive of Yugoslavia), Fond Stanislava Krakova, 102-1-1, Izvod iz knjige venčanih srpske pravoslavne crkve Nove Kragujevačke, tek. br. 33, 4. maj 1938.

12 KRAKOV 2009, pp. 19, 21.

13 KRAKOV 2009, pp. 24, 29. 
to the first frontline. His division was destroyed during the battle for Kajmakčalan, (summer-autumn 1916), while he received another severe injury. ${ }^{14}$

Through many battles Krakow demonstrated obvious bravery, however, in wartime he displayed another, very peculiar talent. He began to keep a diary in the Balkan Wars, writing down all the events he witnessed personally or heard along the road. In an interview for Illustrated War Chronicles, he announced his intention to publish these notes after the Wars but that did not happen, most likely due to the outbreak of new war. ${ }^{15}$ Nonetheless, throughout the entire WWI he continued to write at every free moment. At the Thessaloniki front, writing became his "way out from cruel reality". There in the trenches in 1916, he launched a satirical newspaper called Rovovac. ${ }^{16} \mathrm{He}$ was the author of all articles and illustrations and paid a battalion scribe to make ten additional copies. The universal theme of Rovovac was mocking the absurdity of the war. The newspaper drew widespread attention among soldiers and gained immediate popularity. Nonetheless, his superiors were not thrilled with his daring approach and prohibited the paper after only four issues. ${ }^{17}$ Even so, he did not feel discouraged by this failure. By summer 1918 he managed to finish his first novel Kroz buru (Through a Storm), published under the same title in 1921). Three doctors in his battalion read the manuscript, approved its quality and declared that "Sub-lieutenant Krakow is talented for writing". Encouraged by their praises, he quickly began work on a second novel Krila (The Wings, 1922), which he conceived as a "story about adventures in Thessaloniki and deaths of comrades". He did not have time to finish the manuscript because Headquarters announced an order for the final operation.

\section{Pro-Yugoslav Movement in Croatia and Rijeka}

In the Dobro polje battle, Krakow led a unit of volunteers from Dalmatia and Croatia. ${ }^{18}$ It was at the Second Army's head, advancing quickly from the start, and at some point Krakow referred to them as "lost" since they had been mostly disconnected from the rest of the army. The unit was the first that entered the city of Veles in Macedonia. His unit arrived in Kragujevac on 26 October, marking the end of "a life cycle" for Krakow as he returned to the beginning of his journey. Kragujevac was the city where his parents met, where he was born and from where he left for the war. Though personally important for Krakow, Kragujevac was just one stop for the Serbian army. The entire way marching he was referring to rivers as some imaginary borders in that triumphal endeavor: "We crossed Vardar and Morava, only Sava left to be conquered." ${ }^{19}$ The same day when the First Serbian army arrived in Belgrade, Krakow's Second army liberated Šabac, a city at the Sava River and reached the border with Austria-Hungary. ${ }^{20}$

14 NBS, RO, ASK, P 707/I/1-21; KRAKOV 2009, pp. 161,184-185,190.

15 Ilustrovana ratna kronika, "Stanislav Krakov", 2/15 December 1912, No. 14, p. 16.

16 Journal Rovovac available at http://velikirat.nb.rs/items/show/4033

17 The four publications appeared on 2, 8, 18, and 25 December 1916. Krakow wrote that the paper was forbidden because of one article $A$ protest where he satirically described the protests of mules, horses and bulls at the frontline. His superior officers found it an insulting reference to soldiers that were fighting and dying every day. KRAKOV, Stanislav. Jedan mitning. In Rovovac, 8 December 1916, pp. 4-6.

18 KRAKOV 1928, p. 8.

19 KRAKOV 1928, p. 56

20 KRAKOV 2009, p. 263; KRAKOV 1928, p. 57. 
From the beginning of the War, Serbian Headquarters and the Regent had been aware of strong Pro-Yugoslav feelings amongst South Slavs in Austria-Hungary. With the help of prominent Croatian, Slovenian and Serbian intellectuals, Serbia was helping this great potential to be shaped into a movement. Dissatisfaction with central power started to increase in 1917 and took many forms, the most important was a mass desertion of soldiers. One estimation says that in 1918 there were over 200 thousand deserters, collectively known as Zeleni kadar, because they were hiding in forests and mountains. The majority of the Zeleni kadar movement was located in the southern parts of the Habsburg Empire - Dalmatia, Kordun, Lika, Banija, etc. ${ }^{21}$ The great success of L'Armée D'Orient in September 1918 was a crucial cue for Southern Slavs in Austria-Hungary to start an open rebellion against authorities. At the beginning of October, all over Croatia, Slavonia and Dalmatia, groups of Croats, Slovenes and Serbs began to organize associations of power - National Councils, which replaced officials. The decisive step was the proclamation of the State of Slovenes, Croats and Serbs (The State of SCS) in Zagreb on 29 October 1918. ${ }^{22}$ The president of the State of SCS was Anton Korošec, a Slovenian, while there were two vice-presidents, a Serb, Svetozar Pribićević, and a Croat, Ante Pavelić Senior. The newly founded state immediately expressed a desire to be united with Serbia. ${ }^{23}$

The pro-Yugoslav movement in Rijeka started to mature during 1917 when the most prominent proponents met regularly in Rijeka's city library to coordinate their actions with like-minded pro-Yugoslavs in Zagreb and all around Croatia, Slavonia and Dalmatia. In January 1918, Rijeka's pro-Yugoslavs started a petition indicating that Rijeka should be part of a future Yugoslavia and by 25 January, 6012 signatures had been gathered. Local newspapers also wrote more often about the necessity to create a national state which will bring together Croats, Slovenes and Serbs. ${ }^{24}$

The breakthrough of the Thessaloniki front accelerated the course of events in Rijeka and by mid-October, the situation had high patriotic implications. The town of $54570^{25}$ was divided into three fractions: pro-Italians, pro-Yugoslavs and an autonomous movement. ${ }^{26}$ Italy had been expressing tension toward Istria ever since the unification of the country in 1870, mainly regarding annexing Istria's capital Trieste, but Rijeka was no less important for Rome. Both cities had a tradition of irredentism, which WWI additionally ignited.

21 ČULINOVIĆ, Ferdo. Raspad Austro-Ugarske i postanak jugoslavenske zajedničke države. In ČUBRILOVIČ, Vasa et al. (eds.) Naučni skup povodom 50-godišnjice raspada Austro-Ugarske monarhije i stvaranja jugoslavenske države. Zagreb: Jugoslovenska akademija znanosti i umjetnosti (JAZU), 1969, pp. 17-59.

22 The State of Slovenes, Croats and Serbs was created on the ruins of Austria-Hungary and existed only briefly (29 October-1 December 1918) i.e. in the interim between the disappearance of Austrian power and the establishment of the Kingdom of Serbs, Croats and Slovenes. The State was unrecognized internationally, only being acknowledged by the Kingdom of Serbia. Regarding territory, the State consisted of former parts of Austria-Hungary, (Slovenia, Croatia, Slavonia, Dalmatia, Bosnia and Herzegovina and Rijeka). The state's name is often confused with the name of Kingdom of Serbs, Croats and Slovenes. The difference is that the State of Slovenes was listed as a first constitutional nation, while the Kingdom of Serbs was mentioned first. Also, the State did not have a clearly defined constitutional organisation, it was led by the National Council. The Council's delegation, led by Vicepresident Svetozar Prebićević, issued the decision to blend the State of SCS into the Kingdom of SCS proclaimed in Belgrade on 1 December 1918.

23 EKMEČIĆ, Milorad. Stvaranje Jugoslavije 1790-1918, Vol. 2. Beograd : Prosveta, 1989, p. 806.

24 MARJANOVIĆ, Milan. Rijeka od 1860 do 1918. In RAVLIĆ, Jakša (ed.) Rijeka : geografija - etnologija - ekonomija - saobraćaj - povijest - kultura (below Rijeka). Zagreb : Matica Hrvatska, 1953, p. 248.

25 According to the census from 1910 the national composition of the population of Rijeka was: $48.61 \%$ Italians; 25.95 \% Croats; $4.69 \%$ Slovenes; 13.03 \% Magyars and $4.64 \%$ Germans; in total 49806 people. HOREL, Catherine. Trieste et Fiume, deux aspects de l'irrédentisme Italien 1867-1914. In PAVLOVIC, G. Vojislav (ed.) Italy's Balkan strategies $19^{\text {th }}$ \& $20^{\text {th }}$ century. Belgrade : Institute des études balkaniques, 2014, p. 125.

26 BARBALIĆ, Fran. Pitanje narodnosti u Rijeci. In Rijeka, pp. 15-34. 
Regarding the Yugoslav question, Italy maintained two opposing views: the first was denying rights to Slavs or any other nations, i.e. preaching for the total domination of Italy in the Adriatic Sea and notions of territorial expansion on the Eastern coast, and the second was calling for compromise with the Southern Slavs, the political collapse of Austria-Hungary and the creation of ethnic states on its ruins in the traditional spirit of Risorgimento and Mazzini. ${ }^{27}$

The turning point in Rijeka occurred on 21 October when soldiers from the $79^{\text {th }}$ infantry regiment Ban Jelačić decided to replace the Austrian flag with a Croatian one and to free all political prisoners. Aside from institutions, the new flag was displayed everywhere, including on steamships like the Adrie and the Ungaro-Croate. ${ }^{28}$ The proclamation of the State of SCS in Zagreb triggered the creation of a Rijeka national council on the same day. The Council in Rijeka was headed by Andre Bakarčić, a lawyer and advocate of Ante Starčevićs Party of Rights. The National Council took power from the last Hungarian Governor, Zoltan Jekelfalussy, while as he and the rest of the Austro-Hungarian authorities fled the city. ${ }^{29}$ This was the de iure and de facto end of Hungarian power over Rijeka. ${ }^{30}$ Lieutenant-Colonel Petar Teslić, a former Austrian officer, took over command of the military. He gathered prisoners and the Zeleni kadar and incorporated them into the city's police force. However, the situation began to get complicated when the Italians and their supporters founded Consiglio Nazionale di Fiume. Dr Antonio Grossich, a local medic who interned in Vienna during the War, was elected its president. The creation of an Italian council was the manifestation of local patriotism felt since the London Treaty (singed on 26 April 1915), where Rijeka was excluded from Italy's sphere of interest. Since it was not part of the London Treaty, tension in the city with Italy led to the slogan: "The Treaty of London plus Fiume." ${ }^{31}$ On 30 October, Bakarčić opened negotiations with city commissioner Dr Antonio Vio Jr. and with Dr Grossich. They reached a deal the same day by which Rijeka was proclaimed a part of new the State of SCS in Zagreb and all city power was transferred to the National Council. ${ }^{32}$ After an intervention from Zagreb, Bakarčić was replaced by Dr Ricardo Lenac. Despite the agreement, Italians made an official request the following day to Rome that Rijeka be united with Italy. The reason for such action was a strong belief that the London Treaty must be honored as a prize for declaration of war against AustriaHungary and all endured war efforts. Starting in early October 1918, the Italian army commenced taking Dalmatia, mainly following the borders stipulated by the Treaty. However, during its stay the Italian army crossed that imaginary border on several locations, aiming to apply military pressure upon the ongoing Paris Peace Conference. ${ }^{33}$ Counting on the London Treaty, Italians from Rijeka called upon an Italian fleet anchored nearby in Pula to support their claim. On 2 November, before the Italians arrived at Rijeka's dock, one flotilla of American war ships and one squadron of French and British army soldiers appeared. All three commanders declared that they recognize the National Council of the SCS and the following day they organized an improvised Inter-allied command over Rijeka

27 LATINOVIĆ, Goran. Yugoslav-Italian economic relations (1918-1941). Banja Luka : Univeristy of Banja Luka; Faculty of Philosophy, 2019, p. 13.

28 BARBALIĆ, A. Radojica. Brodarstvo Rijeke kroz vijekove. In Rijeka, p. 110.

29 MARJANOVIĆ 1953, p. 251; KLEN, Danilo - STRĆIĆ, Petar (eds.) Povijest Rijeke. Rijeka : Tipograf, 1988 , p. 285.

30 HOREL 2014, p. 122.

31 LATINOVIĆ 2019 , pp. 13-14.

32 MARJANOVIĆ 1953, p. 225.

33 LATINOVIĆ 2019, p. 13-14. 
in the name of General Franchet d'Espèrey, confirming military command to LieutenantColonel Teslić and his battalion. ${ }^{34}$

When Admiral Giuseppe Reiner Bichat appeared at Rijeka's dock on 4 November, the situation in the city started to worsen. He boarded the warship Emanuele Filiberto and three more ships following. The Italian fleet arrived just a day after a signed armistice in Villa Giusti firmly determined to uphold every point of the London Treaty. ${ }^{35}$ Initially, the arrival of another ally was greeted cordially by all of Rijeka's citizens. Twenty-five thousands people organized a parade in their honor and as a sign of good will, the Italian flag was displayed side by side with the Croatian at the castle. Nonetheless, Admiral Reiner instantly objected, asking that the Croatian flag be removed from the castle and steamships arguing that by naval rules, neither Croatian nor Yugoslav flags were internationally accredited. He proposed that Dr Lenac return the Austro-Hungarian flag - still official, or to display an Italian as flag one of the Allied powers. Dr Lenac declared that returning the Austrian flag is out of the question. Reiner then acted on his own and displayed the Italian flag without his consent. The move created a tense situation between the National Council and Admiral Reiner, and directly caused mutiny among sailors, mostly Slavs, who refused to sail under an Italian emblem. ${ }^{36}$ Reiner remained firm and ignorant toward the sailor's dissatisfaction, instead continuing to take additional measures which clearly indicated preparation for Rijeka's unification with Italy. Despite the open intentions, for time being Reiner decided not to disembark the army from any ships in order to avoid direct conflict with Teslićs battalion and the other armies in Rijeka. Meanwhile, the National Council started to express some anxiety that Teslićs battalion will not be enough protection from the far outnumbered Italian army. Therefore, Dr Lenac called upon help from Zagreb and Serbian Headquarters. Along with an appeal from Rijeka, a special delegation of the State of SCS arrived in Belgrade on 8 November where they met Regent Alexandre two days later. They requested that Serbia send around 500 soldiers to Rijeka as protection from the Italians, 1000 soldiers to Zagreb to implement orders of the National Council, and additional troops to Bačka and Banat to create a barrier against Hungary. The delegation stayed in Belgrade until 12 November and as soon as they left the city, Serbian Headquarters issued orders for two battalions to start marching towards Zagreb and Rijeka. ${ }^{37}$

\section{Krakow's Last Wartime Adventure - Over the Austro-Hungarian border}

Calling the Serbian army came naturally since it had already crossed the border with Austria-Hungary. The first unit was to cross the Sava River on 5 November. The decision was made promptly after group of Serbs came to Šabac and invited the Serbian army claiming that Austria had withdrawn its troops. The task was assigned to Stanislaw Krakow and the 34 soldiers under his command. The Serbian army was unprepared for such a duty,

34 SUČIĆ, Ivo. Rijeka 1918 - 1945. In Rijeka, p. 285.

35 The main target was Dalmatia where the Italian army was arriving on the day of the armistice. By 13 November, the entire Dalmatian coastline and islands were seized by Italians. The idea was to promptly control all Austrian territories and stored ammunitions, and with it to force the Allies to accept Italian rule over the Eastern Adriatic coast as fait accomplice. GULIĆ, Milan. Stupanje srpske vojske na područje Dalmacije, 1918. godine. In RASTOVIĆ, Aleksandar - MILKIĆ, Miljan (eds.) End of the Great War - The Road to New Europe. Belgrade : Institute of History; Strategic Research Institute, 2020, pp. 37-58.

36 BARBALIĆ 1953, p. 110.

37 GULIĆ 2020, pp. 42-43. 
proof of the fact was that Krakow and his unit had only fishing boats at its disposal. ${ }^{38}$ Later, Krakow described the crazy feeling that he had, "I was sent to conquer an Empire with only a handful of people". ${ }^{39}$ Krakow's unit had been part of a battalion under the command of Lieutenant Colonel Ljubomir Maksimović, known among soldiers by the unique nickname Ljuba the God. ${ }^{40}$

The first town Krakow's unit reached was Ruma. There, Serbian soldiers were welcomed by 600 Czech Legionnaires which sang the pan-Slavic anthem Hey, Slavs in their honor. ${ }^{41}$ Describing the euphoria in the city, Krakow wrote that they felt "Ruma as some triumph gate trough which we entered into Yugoslavia". ${ }^{42}$ The next ten days, Krakow crossed the entire Fruška Gora region along with some prominent locals. On that journey they did not

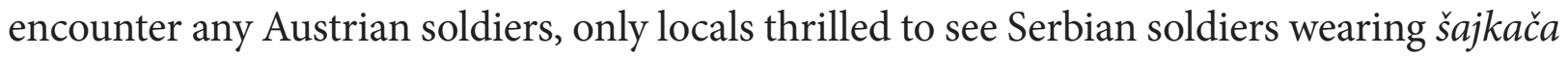
a Serbian national cap. For them, šajkača was a symbol of freedom. ${ }^{43}$ Until 12 November Krakow and his group crossed almost the entire Srem and Bačka regions when he received an order from Serbian Headquarters to redirect their actions towards Zagreb and Rijeka. ${ }^{44}$

Before they crossed Croatia's border, Regent Alexander and Chief of Headquarters Vojvoda Mišić consulted General Franchet d'Espèrey on the matter. D'Espèrey gave them the green light. That decision was riskier because it had the implication of a possible open conflict with an ally's army - the Italians. For that reason, the mission was classified as top secret with the main goal that the army reach the Adriatic coast before the Italians do and to put the entire Adriatic seaboard under the control of L'Armée D'Orient. This task was given to the battalion under command of Lieutenant Colonel Maksimović with Stanislaw Krakow, upgraded to Lieutenant, his deputy commander. The battalion set off on 12 November. ${ }^{45}$

Even though the mission was classified as top-secret, the battalion was given a special train fully decorated with flowers and Serbian flags. Soldiers were cheerful, singing with fifes and trumpets all along the way. ${ }^{46}$ Such a decorated and noisy train drew attention wherever it went. In each city the train passed through, locals cheerfully welcomed the Serbian soldiers. The warm receptions evoked the most excitement among soldiers, wrote Krakow, and even the Spanish flu could not spoil their happiness. The first stops on their journey were Vinkovci and Slavonski Brod. In Slavonski Brod, a local National Council organized parade most warmly greeting Serbian soldiers "as those who bringing peace and liberation". The train arrived in the Croatian capital, Zagreb, on 14 November but the atmosphere was much colder than in previous locations. ${ }^{47}$ Only a few members of the National Council and the State of SCS led by Svetozar Pribićević were at the train station as it arrived in the early morning. There was no parade or joyful locals. Krakow's impression was equally cold as the reception, he was not even impressed with the famous Pribićević, describing

38 KRAKOV 1928, p. 58.

39 AJ, 102-4-9, Govor S. Krakova na svečanosti povodom 20. godina od oslobođenja Rume, 5-6 November 1938.

40 Maksimović's battalion was excluded from the Yugoslav Volunteer division, which was under the command of General Vojislav Živanović at that time. KRAKOV 2009, pp. 260-261; KRAKOV, Stanislav. Naše poslednje pobede. Od Kajmakčalana do Rijeke na čelu jurišnog voda. Beograd : Društvo Nova Iskra; Slava, 2010, p. 81.

41 KRAKOV 2009, pp. 266-267.

42 AJ, 102-4-9, Govor S. Krakova na svečanosti povodom 20. godina od oslobođenja Rume, 5-6 November 1938.

43 KRAKOV 2010, pp. 85-86.

44 KRAKOV 2009, p. 274.

45 KRAKOV 2009, p. 274.

46 KRAKOV 1928, p. 62.

47 TEŠIĆ, Gojko (ed.) Crveni pjero i druge novele. Beograd; Arandjelovac: Filip Višnjić; Napredak, 1992 , p. 89. 
him as "a gloomy fanatic with dangerous ambitions". ${ }^{8}$ After a short break, the train continued towards its final destination arriving on the $15^{\text {th }}$ early in the morning. The moment the soldiers saw Rijeka and the sea there was an eruption of happiness, they were cheering and singing and it "was so hard to restrain them not to shoot in the air" ${ }^{49}$ Krakow noted that it was a moment of great historic significance for all of them and he truly believed that if it were required of them to confront the entire Italian army in the fight for Rijeka, they would be unstoppable. The reception in Rijeka for the Serbian soldiers was the most festive. At the train station they were greeted by a delegation comprised of Dr Lenac, members of the Rijeka and Istria National Councils, an orthodox priest and Lieutenant Colonel Teslić. All of them had ribbons around arms in the colors of the Serbian and Croatian flags. ${ }^{50}$

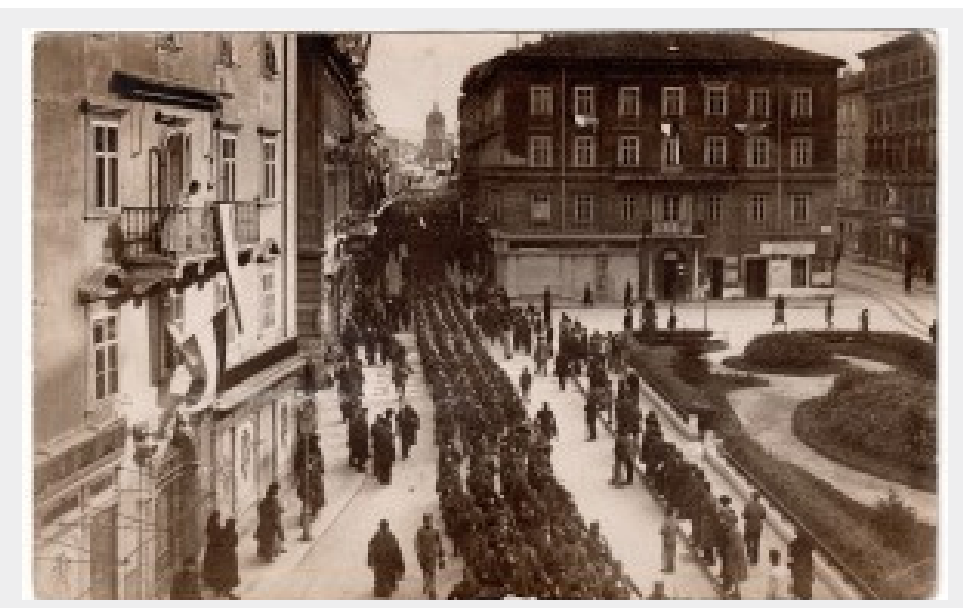

Figure 2. Arrival of the Serbian army in Rijeka. Source: MUO-019629/01 https://repozitorij.muo.hr/?pr=i\&id=52173 [last viewed on 14 June 2021]
The arrival of the Serbian army pushed an already tense situation in the city to almost open conflict. Admiral Reiner was shocked when heard that they had come directly from the Thessaloniki front. He repeated continuously that is not possible. Like was done for Italian army, Rijeka's citizens organized a welcome parade for Serbian army. According to Krakow, the occasion brought over 30 thousand people to Rijeka's streets. However, the celebra-

tion did not last long. Reiner immediately requested to disembark the Italian army since the Serbian army was already there. This demand led him into a dispute with Maksimović. An almost inevitable clash between them was prevented by French, British and American officers. Krakow wrote that Captain Georges Durand-Viel, commander of French torpilleur Touareg, had the most important role, "he was some sort a buffer between Maksimovićs stubbornness and Reiner's arrogance". Aiming to settle the differences among Serbs and Italians, allied officers scheduled some sort of inter-allied conference for 17 November. Meanwhile, one British and one American battalion arrived from the Piave River and those officers joined the meeting. At the conference, the officers decided to temporarily put Rijeka under the protection of the Entente, thus Maksimović was advised to withdraw his soldiers to Kraljevica at the Croatian coastline. The idea was that only French, British and American soldiers stay in the city. Until the final decision, Reiner promised that the Italian army will not enter Rijeka. At 3:45 pm on 17 November, two ships with the Serbian army left Rijeka's dock. Maksimović kept his word, but as soon as the ships embarked, Reiner gave the signal for army landing. ${ }^{51}$ Simultaneously, one infantry division under

48 KRAKOV 2009, p. 300.

49 KRAKOV 1928, p. 64.

50 KRAKOV 2009, p. 274.

51 KRAKOV 1928, p. 67. Regardless of the fact that the Serbian army had withdrawn to Sušak, this location was also questionable. The Kingdom of Serbs, Croats and Slovenes got right over this harbour in 1922 by an agreement in Santa Margherita. The Italian army left Sušak in March 1923 when Yugoslavia put the city under its control. BARTULOVIĆ, Željko. Talijanska okupacija Sušaka 1918-1923. In JURKOVIĆ, Ivan (ed.) Zbornik u čast Miroslava Bertoše, Vol. 3. Pula : Sveučilište Jurja Dobrile u Puli, 2013, pp. 159-178. 
the command of General Di San Marzano appeared from the north and 25 thousand fully armed soldiers marched into the city and in just few hours the Italians took full control of Rijeka. ${ }^{52}$ This ended the very short Serbian control of Rijeka, lasting only two days. Including the pro-Yugoslav ruling, it was 18 days in total.

Reiner's disloyal and disrespectful act caused great bitterness within the Serbian army and pro-Yugoslavs in the city. In the following days and months, the situation escalated into open fights between Italians and Yugoslavs in the city's streets. The state of affairs aggravated people not only in Rijeka, but in Italy as well. All around the country there were organized demonstrations against Croats and Yugoslavs, while Rijeka been transformed into a "martyr city". Hatred was directed against Serbia as well with the justification that Italy contributed the most during the operation to save the Serbian army in 1915 and that Serbia is now ungrateful with their posturing towards the Adriatic coastline. Nationalists of every sort were calling people to stand up for the rights of Italians. The loudest was prominent poeta-soldato Gabrielle D'Annunzio, who had a link with Serbia long before Rijeka. After the defeat of the Serbian army in November 1915, he dedicated Oda alla nazione serba to Serbia. In the poem, he praised Serbian bravery and its affection towards the Serbian people. The poem was translated by prominent Serbian poet Milutin Bojić and published in the Serbian newspaper in Corfu at the beginning of $1916 . .^{53}$

With the crisis around Rijeka, D'Annunzio's affection towards Serbia vanished. At the protests, he came up with the famous mantra "Fiume o morte", which was immediately converted into Rijeka's version as "Italia o morte". ${ }^{54}$ In the following months, Non-Italians in Rijeka changed the saying into "Italia è morte", and referred to Italian rule as "terror". 55 The official transfer of power come about on 7 December when Consiglio Nazionale declared itself an independent body with "governmental power". ${ }^{56}$ Benito Mussolini arrived in Rijeka on 20 December and gave a speech in the city theatre, but the general impression of that address was very mild. ${ }^{57}$ When it comes to other great powers, France supported from the Yugoslav standpoint from the beginning of the crisis because it was better to deal with a smaller state like Yugoslavia instead of letting Italy control the entire Adriatic Sea. Before the Italians managed to seize the city, the French tried to take control of Rijeka with the support of the Yugoslav National Council but the attempt failed and they gained only one small harbor. ${ }^{58}$

Leaving Rijeka on 17 November was the end of Maksimovićs mission, but not the end for Stanislaw Krakow. When his comrades left Kraljevica few days later, Krakow returned to Rijeka as a representative of the Serbian army with a new mission from French General Charles Tranié, commander of the $122^{\text {nd }}$ French division at the Thessaloniki front. This mission was created under the authority of General D'Esperèy. Tranié arrived shortly after the Serbian battalion, also directly from Thessaloniki front, at the head of a battalion taken from the $11^{\text {th }}$ French colonial division. Acting in the name of General D'Esperèy, Tranié was commander of all international allied forces located in Rijeka. Besides the French

52 KRAKOV 2009, p. 282.

53 KRAKOV 2009, p. 291.

54 SUČIĆ 1953, pp. 277-304.

55 SUČIĆ 1953, p. 287.

56 MARJANOVIĆ 1953, p. 251.

57 SUČIĆ 1953, p. 289.

58 SUČIĆ 1953, p. 289. 
battalion, it included a British and an American regiment. He personally drew the hatred of Italians who accused him of being the "biggest protector of Croatian rights over Rijeka". According to Krakow, Traniés role was merely symbolic because in realty, the Italians controlled everything..$^{59}$ Krakow was part of Traniés mission until 20 December after which, by order of the Serbian Headquarters, he was relocated to Zagreb. At departure he expressed the deepest sense of "anxiety and uncertainty" and closure, "Rijeka was our last triumph and the first defeat at the same time".60

\section{Krakow's Relations Toward Italy in the Kingdom of Serbs, Croats and Slovenes / Yugoslavia}

The Kingdom of Serbs, Croats and Slovenes was officially proclaimed in Belgrade on 1 December 1918. According to opponents, such unification was conducted in haste without profound discussion or preparation. Bosnia and Herzegovina, Srem and Vojvodina, as parts of former Austria-Hungary had referendums about unification, but Croatia, Slavonia, Dalmatia and Slovenia did not have that option. In their case, the union was accepted by a special delegation of the State of SCS led by Svetozar Pribićević, which was sent to Belgrade at the end of November with the task of negotiating the conditions of unification with Regent Alexander. Talks lasted only one day as Pribićević acted hastily and agreed to all proposed terms without consultation with Korošec and the Council in Zagreb. The main conditions were that the state be organized as a hereditary and centralized monarchy with the Karadjordjević dynasty at the head, and all previous historical differences will be annulled, including national assemblies. In the new state, there will be just one Assembly in Belgrade, the Serbian dinar will serve as the official currency and all armies will be unified and organized under the standards of the Serbian army.

When these conditions were disclosed in a public proclamation of the new state it caused great discontent in Croatia. People had the impression that they were being treated as defeated. Dissatisfaction with the conditions reached the highest level in Zagreb and a rebellion occurred on 5 December (Petoprosinačka pobuna) five days after the proclamation. ${ }^{61}$ The main request of the protestors was independence for Croatia. During the unrest, republican protestors got into a fight with soldiers from the $25^{\text {th }}$ and $53^{\text {rd }}$ infantry regiments along with volunteers from Dalmatia and members of Sokol. Thirteen people were killed, nine of them republicans while 17 in total were injured. The Serbian army did not help in suppressing the rebellion but afterwards it seized the opportunity to put Zagreb under its control and to dismiss all pro-republican officials from governing. This rebellion was later praised by Ustashi during the Second World War (WWII) as the first reaction against Great-Serbian hegemony, while the rebellion's victims became martyrs. In order to ensure safety in Zagreb and to ease the transition of Croatia into a new state, Serbian Headquarters created a mission for Colonel Pribićević, Svetozar's brother. Krakow arrived in Zagreb to join this mission as a liaison officer just two weeks after the rebellion. In February 1919,

59 SUČIĆ 1953, p. 292.

60 TEŠIĆ 1992, pp. 87-92; BABIĆ, Dragan. Putujuća tragedija : Prvi svetski rat i novele Stanislava Krakova. In DEMIĆ, Mirko (ed.) Stanislav Krakov - avangarda, margina, nasleđe. Zbornik radova o stvaralaštvu Stanislava Krakova (1895-1968). Kragujevac; Inđija : Narodna biblioteka Vuk Karadžić; Komazec, 2015, pp. 53-68.

61 GEIGER, Vladimir - BARIĆ, Nikica. Odjeci i obilježavanja 5. prosinca 1918. u Nezavisnoj državi Hrvatskoj. In Časopis za suvremenu povijest, 2002, Vol. 34, No. 3, pp. 833-850. 
the Pribićević mission was replaced with new one headed by Colonel Milan Nedić, Krakow's uncle, where he held the same position. ${ }^{62}$

From Zagreb, Krakow continued to follow Rijeka's state of affairs. He was familiar with more frequent confrontations in the city streets and that Yugoslavs were forced to move to other areas. ${ }^{63}$ At the same time, Rijeka become very appealing for Italian nationalists seeking to extend the war. Rijeka's crisis was transformed from a local issue into a question of national pride for every Italian. Tensions continued to increase month by month which forced the Allies gathered at the Peace Conference in Versailles to intervene and they made the decision to dismiss Consiglio Nazionale. This was followed by the limitation of Italian soldiers in Rijeka to just one brigade while the rest were replaced with a mixed EnglishAmerican squad in the capacity of international police. Their arrival was scheduled for 12 September but Colonel Gabrielle D'Annunzio entered the city a few hours before the foreign forces. He arrived with a "group of volunteers", calling this maneuver poetically "Santa entrada" and instantly proclaimed Rijeka's annexation to Italy. With this proclamation, Rijeka once again became corpus separatum. Officially, Rome did not accept the city's annexation declaring that "Santa entrada" was an individual act. Nonetheless, in the following months there was no doubt that D'Annunzio acted with approval from officials. Italy started a diplomatic operation in order to persuade other great powers to acknowledge Rijeka as a "pillow state" under protection of the League of Nations. ${ }^{64}$ Negotiations regarding the status of Dalmatia and Rijeka began in March 1920 and went through several phases. The first concluded with an agreement signed on 12 November 1920 in Rapallo near Genève where the Italians agreed to withdraw the majority of their troops from the larger part of Dalmatia. By the Treaty of Rapallo, Italy recognized the Yugoslav state and admitted the possibility of cooperation between the two countries. The second phase of negotiations was resolved with the Brioni Conventions in September 1921, which regulated fishing in the Adriatic Sea. This was the beginning of the final phase. ${ }^{65}$ Rijeka's status was definitively resolved by Rome's contract, i.e. the pact of friendship between Yugoslavia and Italy concluded on 27 January 1924. With Rome's contract, Yugoslavia renounced its claims and gave freedom to Italy to integrate Rijeka into its borders. The seizure of power by Fascists in Italy at the end of October 1922 paradoxically led to an improvement of relations, owing to Mussolini's efforts towards international consolidation. One of the points of the fascist program created in the manner of "new and dynamic foreign policy" was "reconciliation and balance with the Yugoslav state". ${ }^{66}$

Krakow stayed in Zagreb until May 1919, after which he was reassigned to other tasks. By 1924 his life had completely changed. After suicide attempt in 1921, he retired from the army the following year and started a career as a writer and journalist. ${ }^{67}$ In that time,

62 KRAKOV 2009, pp. 300, 308-309.

63 In Dalmatia, there were many conflicts between the Serbian and Italian armies, mostly in places outside the imaginary border drawn up in the London Treaty. In these confrontations, the Italians outnumbered the Serbian army and were far better armed. Serbian Headquarters issued an order on 30 December to its troops to avoid any open clash with the Italians. The difference between Istria and Dalmatia was that in Istria, there was not any Serbian army presence and the sporadic conflicts occurred between pro-Yugoslav civilians and the Italian army. GULIĆ 2020, 54-57.

64 ČULINOVIĆ, Ferdo. Rijeka u državnopravnom smilsu. In Rijeka, p. 271.

65 LATINOVIĆ 2019, p. 16.

66 LATINOVIĆ 2019, p. 17.

67 The public speculated widely regarding the reasons for his suicide attempt. During the investigation, he declared that he had felt humiliated by his position in the army after the war, mostly because the state accepted the military 
Krakow got closer to the extreme right movements in Yugoslavia like ORYUNA and ZBOR. ${ }^{68}$ The leader of ZBOR, Dimitrije Ljotić, was his best friend from the Thessaloniki front. Both organizations enlisted former soldiers and were considered defenders of unitary Yugo-Slavism, i.e. an ideology which considered Serbs, Croats and Slovenes parts of the same people but with three different names and two religions. This ideology was accompanied by a belief that if three constitutive nations and over 20 different nationalities live in a firm unitary system, eventually all will transform into one nation - the Yugoslavs. Opposing official ideology was the idea of a federal or system promoted by Croats and Slovenes during the War. After Yugoslavia was made pro-federalist, it started favoring decentralization and campaigning that centralization is just camouflage for a Great Serbian imperialism. In order to suppress opponents, the King decided to impose dictatorship in 1929. This act was accompanied by his memorable statement: "We created Yugoslavia, and now is the time to create Yugoslavs." As former solider, monarchist and patriot, Krakow strongly believed in Yugoslavia and that his task was to protect the country no matter what. He did not hesitate if needed to physically defend the state and its ideology. He was one of leaders of bully groups in ZBOR known for getting into fights with opponents. ${ }^{69}$

Under such tense political circumstances, it seems that the loss of Rijeka due to the Roma agreement did not affect Krakow much. As a journalist, in 1926 his interview with Mussolini was published in the daily newspaper Vreme. Neither of them mentioned Rijeka in the interview, but Krakow was highly impressed with Il Duce's appearance and character, stressing that he is the most impressive person that he had met in his entire life. He even underlined the fact that after the meeting he clearly understood why Italians trusted him to lead them. For Krakow "He was a politician who clearly knows what he wants and how to achieve his goals". Because of these remarks, he was severely criticized in public opinion as pro-fascist. Even so, Krakow's admiration for Mussolini did not last much after the interview. When the Italian press started a ferocious campaign against Yugoslavia over quarrels in the League of Nations, Krakow felt personally insulted and started to respond with equal hostility in Vreme. In his articles, he was mostly mocking Italian heroism in the War. He went so far that Rome placed him on the black list and from 1932, he was officially a persona non grata in Italy. The last and harshest article Heroji sa Kaporeta (Heroes from Caporetto) was published by Krakow on 9 September $19344^{70}$ The article was released a month before

ranking of former Austro-Hungarian soldiers and placed them in an equal category as those from Serbia. Even though he was a supporter of Yugoslavia, he identified himself first as a Serb. Another version was unrequited love for some lady. He wrote a short story about it titled "How I Killed Myself". KRAKOV, Stanislav. Kako sam se ubio. In Vreme, 1926, No. VI/1456, pp. 6-8, 25; POTREBIĆ, Milan. Dva opisa samoubistva u pripoveci "Kako sam se ubio" i memoarima Život čoveka na Balkanu Stanislava Krakova. In Zbornik Matice srpske za slavistiku, 2018 , Vol. 93, No. 1, pp. 265-283.

68 ORYUNA - The Organisation of Yugoslav Nationalists existed from 1921 until 1929 as an extreme-right political organization influenced by Fascist ideology. It was the most influential in Dalmatia and Croatia and ideologically fought against Croatian separatism. As such, it was forbidden in the dictatorship. BARTULOVIĆ, Niko. Od Revolucionarne Omladine do Orjune. Istorijat jugoslovenskog omladinskog pokreta. Split : Direktorium Orjune, 1925, pp. 104, 106, 108; GLIGORIJEVIĆ, Branislav. Organizacija jugoslovenskih nacionalista (Orjuna). In Istorija XX veka, 1963, Vol. 5, No. 1, pp. 330, 353-357. ZBOR - The United Militant Labour Organisation was founded in 1935. It was a pro-fascist party which was supported financially by the Nazis. In elections 1935-1938 they garnered $1 \%$ of total votes. In the period 1941-1944, it was part of the puppet government of Milan Nedić. Ljotić died in an automobile accident in 1945 in Slovenia where he had escaped with a majority of his followers. Osnovna načela i smernice Jugoslovenskog pokreta “ZBOR” : 1935-1991, Jugoslovenski narodni pokret “ZBOR”, 1991.

69 NIKOLIĆ, Kosta. Komunisti u Kraljevini Jugoslaviji. Od socijal-demokratije do staljinizma 1919-1941. Gornji Milanovac: LIO, 2000, p. 159.

70 BEREC, Nebojša. Stanislav Krakov: jedna biografija. In Zbornik Matice Srpske za društvene nauke, 2016, Vol. 157/158, pp. 637-668. 
King Alexandre was assassinated in Marseilles. After the assassination, there was speculation that Krakow has provoked Fascists with this article to collude with Ustashi against the Yugoslav King, but those claims were never verified..$^{71}$ Another unsubstantiated rumor was that Krakow neglected contact with Fascists when found the link with Nazis. The fact was that he had exclusive rights to write opinion pieces about Germany during the 1930s and that he traveled there frequently where he met some of the most prominent Nazis. In Serbian archives there is no proof that he was on some Nazi favorite list as was claimed by his enemies.

As a cinephile, Krakow worked closely with the most prominent German actors and directors. According to Krakow's daughter, Fritz Lang was a family friend. In the inter-war period he made a few movies but only one has been preserved For the Fatherland's Glory a depiction of Serbia's war experience from the outbreak until the end of WWI. ${ }^{72}$ Explaining the process of film making, Krakow wrote that he was asked by a film studio to arrange many short original videos they had from the war period. He described that work as "putting together some fragmented mosaic as a putting together memory for all comrades and thousands of combatants alive and dead, known and unknown heroes". ${ }^{73}$ Along with those materials, Krakow managed to find original short movies made by French, British, American, German and Austrian war filmmakers. In one film made by a French filmmaker, he had the starring role in the liberation of Veles in Macedonia. ${ }^{74}$ The premier of For the Fatherland's Glory was held on 2 May 1930. The first version was without sound, though later the movie was upgraded and the film with audio was released to the public in $1938 .^{75}$ When WWII broke out, Krakov hid the movie by burying it near the town of Mionica. It was discovered by OZNA (Odjeljenje za zaštitu Naroda, Department for People's Protection) in 1944 after Krakov escaped the country and placed in the collection of forbidden movies where it was forgotten until 1992. In March 1992, Krakov's movie was discovered and presented to the public under the new title Golgotha of Serbia. An interesting fact is that the movie was meant to be inspirational and raise people's spirits towards the new war. The Yugoslav Film Archive restored the movie and classified it as a part of national cultural heritage. It is listed as one of the most important documentary movies, registered under number $106 .{ }^{76}$ Besides an affection towards cinema, during the inter-war period Krakow was a passionate collector of books (his private library had 10 thousand books), philatelist, numismatic and one of the biggest collectors of Serbian medieval arts. ${ }^{77}$

Though his writing career was short (1919-1931) during that period he published six novels: Kroz Buru (Through a Storm, 1921); Krila (The Wings, 1922); Kroz Južnu Srbiju, (Through Southern Serbia, 1926); Naše poslednje pobede (Our last victories, 1928); Plamen četništva (The Chetniks Flames, 1930) and Prestolanaslednik Petar (Crown Prince Petar, 1933). Besides those six, in emigration he published two more novels, both dedicated to his

71 BEREC, Nebojša. Stopama Stanislava Krakova. In Bratstvo, 2017, No. 21, pp. 163-204.

72 KRAKOV-ARSENIJEVIĆ, Milica. Sećanje na oca. In TEŠIĆ, Gojko (ed.) Život čoveka na Balkanu. Beograd : Naš dom; L’Age d'Homme, 2009, p. 8.

73 KRAKOV, Stanislav. Za čast otadžbine (Scenario za film). Požar na Balkanu (Lista natpisa za istorijsko-dokumentarni film). Edited by Gojko Tešić. Beograd : Narodna knjiga; Alfa, 2000, pp. 7-9.

74 KRAKOV 1928, p. 29-37.

75 KRAKOV, Stanislav. U Beogradu se izrađuje veliki film “Za čast otadžbine”, koji će najbolje izraziti naše napore i borbu za slobodu. In Vreme, No. 2887, 6 - 9 January 1930, p. 5; KRAKOV 2000, pp. 85-88.

$76 \mathrm{https} / /$ www.blic.rs/kultura/vesti/zabranjivani-i-skrivani-film-golgota-srbije-stanislava-krakova-u-petak-u-sanu/ hg2vem2 [last viewed on 14 June 2021]

77 KRAKOV-ARSENIJEVIĆ, 2009, p. 8. 
uncle Milan Nedić and his own role in occupied Serbia 1941-1944: General Milan Nedić, $I$ - II $(1963,1968) .{ }^{78}$ In emigration he had the intention to publish his memoires but died before finishing the manuscript. His daughter, Milica Arsenijević Krakow, gathered his notes and with Gojko Tešić published the memoires in 1997 under the title Život čoveka na Balkanu (The Life of a Man in the Balkans). Besides novels, he published mostly short stories in various literary magazines and daily papers. His universal inspiration was WWI, so most of his works had a historical connection with personal experience. To the Rijeka episode he dedicated the novel Our Last Victories, the short story Pobednik (Victor) and part of the memoires (1997). Despite the fact that Krakow's writing career was brief, nowadays he is considered one of the most important Yugoslav representatives of Expressionism. His writing style has been described as "modern, vanguard and in accordance with modern tendency in European prose". ${ }^{79}$

The outbreak of a new war in 1941 turned Krakow's life upside-down. Overnight the country he had fought for and believed in disappeared. Young King Peter II and the government left the country after he signed a letter of capitulation. Nonetheless, Krakow stayed in the country and stood by his uncle's side. When Milan Nedeć was assigned as Serbia's governor under Nazi occupation, Krakow was in charge of public relations. He was editor of propaganda newspapers Novo Vreme, Obnova, Tribina etc., though he was not satisfied with the role he played. After the war, he wrote that he did not have any choice but to act according to the circumstances. He was arrested five times by the Gestapo under the accusation being $\mathrm{Jew}^{80}$ and every time he was saved from prison by his uncle and friend Djordje Rošs, the general consul of Norway. When Nedićs regime collapsed in autumn 1944, he managed to escape the country with his wife and daughter and for the next two decades, went into hiding in Austria, Switzerland and France under a false name and nationality. In his absence, he was sentenced to death three times while all his properties, including a collection of antiquities, were confiscated by new Communist authorities. According to Krakow's daughter, the biggest unfulfilled wish of her father was to return and die in Serbia. He never stopped moaning over Yugoslavia's unfortunate fate and strongly believed that the state he bled for had been destroyed due to wishes of western powers. ${ }^{81}$

The place of Stanislaw Krakow in contemporary history and collective memory is still ambiguous. Some researchers believe that he was a hero of WWI who turned into a traitor and quisling in WWII. Others think that he was unjustly stigmatized by Communists and that they are responsible for such a negative image of him. ${ }^{82} \mathrm{He}$ personally considered himself

78 KRAKOV, Stanislav. General Milan Nedić. Na oštrici noža (1). München : Iskra, 1963, p. 318; KRAKOV, Stanislav. General Milan Nedić. Prepuna čaša čemera (2). München : Iskra, 1968, p. 497.

79 KRAKOV, Stanislav. Pobednik. In Radikal, No. I/38, 27 November 1921, pp. 2-3.

80 The accusation of Jewish heritage was launched by Stjepan Radić, leader of the Croatian Peasant Party in 1926. From the first moment of their interaction in Zagreb in 1919, Krakow was described by Radić as a "semi-blind, and always dissatisfied rebel". They were opponents until Radićs death in 1928. Krakow claimed that he was not a Jew and that his father was a Catholic converted into Protestantism in order to be eligible for a second marriage with his mother. He had a brother from father's side living in France with whom he kept contact. In the interwar period, Krakow travelled several times to Poland and researched his family lineage. Today in his fund stored in Archive Yugoslavia, there are a few documents written in Polish which indicate the Jewish origin of the Krakow family. AJ, Fond Stanislava Krakova, No. 102; KRAKOV 2009, p. 295.

81 KRAKOV-ARSENIJEVIĆ 2009, p. 7.

82 Half a century after death Krakow continues to intrigues contemporary writers, he appeared as character and inspiration in two recent novels Pustolovine Bačkog Opsenara (The Adventures of the Bačka's Illusionist) and Veliki 
misunderstood: "a travelling disaster, a lost man from the lost generation, just one of many unfortunate heroes from the $25^{\text {th }}$ hour." Stanislaw Krakow died on 15 December 1968 in Saint-Julien-en-Genevois, on the border of Switzerland and France. ${ }^{83}$

juriš (The Big Rush): DEMIĆ, Mirko. Pustolovine Bačkog Opsenara. Beograd : Dereta, 2018, p. 228; VLADUŠIĆ, Slobodan. Veliki Juriš. Beograd : Laguna, 2018, p. 481.

83 KRAKOV, Stanislav. Uvodna reč, u Parizu, 1968. godine. In Život čoveka na Balkanu, 2009, pp. 11-13; KRAKOV-ARSENIJEVIĆ 2009, p. 9.

\section{Cite:}

STOJIĆ, Biljana. Yugoslav Ruling Of Rijeka (Fiume) in 1918, Seen by Stanislaw Krakow. In Forum Historiae, 2021, Vol. 15, No. 1, pp. 48-63. ISSN 1337-6861. DOI: https://doi.org/10.31577/forhist.2021.15.1.5

\section{Biljana Stojić}

Istorijski Institut Beograd

Knez Mihailova 36/2

11000 Belgrade

E-mail: biljana.stojic@iib.ac.rs 